\section{Game Birds Increasing}

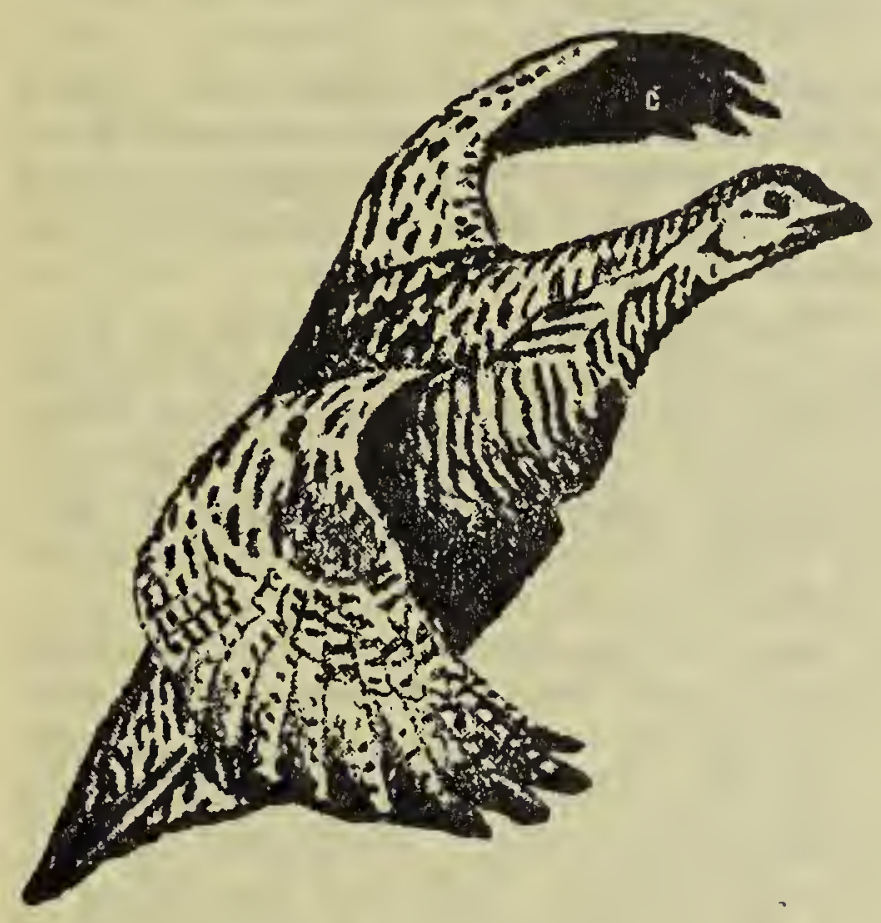

H A R L D D E I G T ON, game guardian at Yorkton believes that the Prairie Chickens as well as the Hungarian Partridges are increasing in number in the district east and south of Yorkton. His opinions are based on a two day survey from the air made in March.

$\mathrm{He}$ and another member of the game branch had toured the area around Saltcoats and Rokeby and during the two days counted 194 Sharp-tailed Grouse along country roads. He believes the chicken population is just about at a peak now.

More timber wolves have wandered south this year than in the past. Formerly they were occasionally reported in the Madge Lake district but this season they have been noted at Margo, Invermay, Sheho and a few miles east of Yorkton.

\section{RUFFIES}

\section{Stuart Francis}

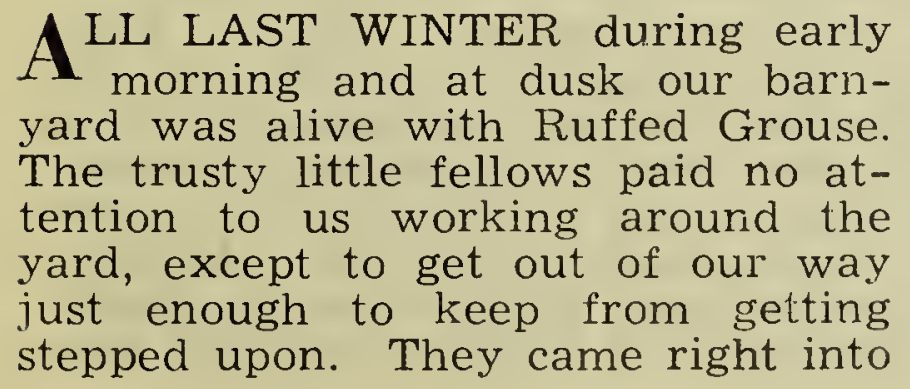

the barn when the doors were open -coming in one door and out the other, just like domestic fowl.

We have two cats around the barn, but they do not attempt to harm the Ruffies, as we call them. They have learned from experience that we will not allow it.

A few years ago these birds did not seem to care for grain but preferred the buds of the Blacis and the White Poplar, never touching grain or sheaves in the yard. Now tree buds seem to be their second choice.

\section{Moose at Torch River}

C. Stuart Francis

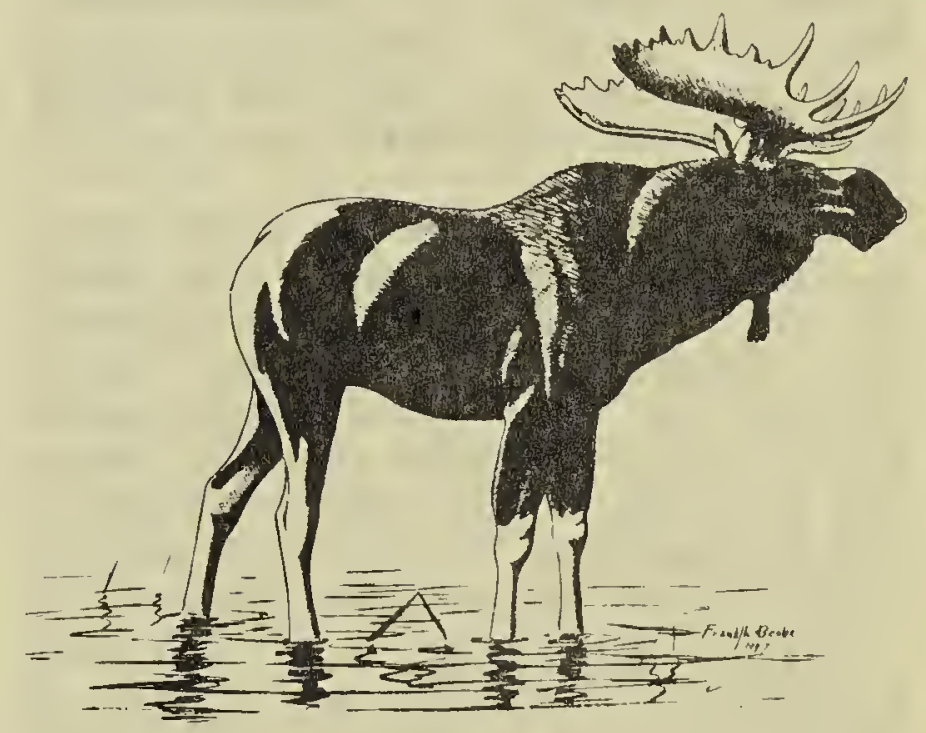

DURING THE WINTER my son and I were cutting and hauling sawlogs from some of our land a mile and a half distant from the home farm. One day, upon arrival at the place where we were working, a fine large pair of moose were feeding about. They were leisurely eating various species of brush and second growth trees. We watched them for several minutes at a distance of about 70 yards. They were feeding on Balsam Poplar, Speckled Alder, Dogwood, as well as on the tip branches of Balsam Fir.

While feeding they would occassionally shake themselves, just like a horse would do. It was a pleasant experience to watch these grand Monarchs of the dark forests in their natural surroundings, especially as they now are getting so few in numbers as compared to 20 or 25 years ago. 